\title{
Joint Venture as a Model of Cooperation in the Infrastructure Projects in Indonesia
}

\begin{abstract}
Submitted 14/01/20, $1^{\text {st }}$ revision 09/02/20, $2^{\text {nd }}$ revision 15/03/20, accepted 29/04/20
Abstract:

$$
\text { Irawan Soerodjo }{ }^{1}
$$

Purpose: This paper aims to present the advantages of a joint venture in the infrastructure development projects with a case study from Indonesia.

Design/Methodology/Approach: The article used the normative approach by taking examples of joint ventures comparing them with other projects in infrastructure.

Findings: Joint Operation is a model of cooperation between two parties, where the first party owns or provides facilities, and on the other party is the owner or provider of funds or having the ability or expertise to support the implementation of the work or project.

Practical Implications: Joint Operation body can act and represented by the Board of Directors as in the case of a Limited Liability Company.

Originality/Value: Joint Operation is not a formal legal entity, but as a quasi legal entity, because the formation of a Joint Operation body is based on mutual agreement, without having to obtain authorization from the authorities.
\end{abstract}

Keywords: Joint Venture, Joint Operation, cooperation, partnership.

JEL Code: K23.

Paper Type: Research study.

\footnotetext{
${ }^{1}$ Dr. Soetomo University (Unitomo), Surabaya, Indonesia, e-mail: irawansoerodjo.unitomo@yahoo.com
} 


\section{Introduction}

Community participation is needed to carry out development in all fields, one of which is public facilities and infrastructure (Paul, 1987). The construction of public facilities and infrastructure is expected to be utilized by the community to carry out economic activities in accordance with their respective sectors or fields. With the increasing need for public facilities and infrastructure, this encourages the government to carry out development, so that it can sustainably support the economic development. In the implementation of the construction of public facilities and infrastructure, it cannot only rely on or involve the role of the government, whether done directly or through a State-Owned Enterprise or a Regional-Owned Enterprise but it needs to involve the participation of the private sector through a cooperation program (joint partnership) (Koppenjan, 2005). Cooperation with the private sector is considered as one of the ways to support the acceleration of the development of facilities and infrastructure, bearing in mind that the private sector is considered to be a party that has sufficient funding or capital and expertise (Cieślik et al., 2019). With this provision, it is hoped that cooperation with the private sector will be able to assist government programs in realizing the construction of infrastructure facilities, all of which lead to the achievement of a just and equitable national development goal for the state.

The pattern of cooperation between the private sector and the government can be done by a way of cooperation in the form of a Joint Operation (JO) (Jayady et al., 2013; Ophiyandri et al., 2017). In addition to other forms of cooperation, such as Build Operate and Transfer (BOT) (Wibowo, 2005; Wibowo et al., 2012), Joint Venture or other cooperation models as the pattern of Joint Operation (JO) is not only limited to cooperation between the government and the private sector, but can also be applied to cooperation between two parties from the private sector. In a cooperation between private parties the parties certainly do not have the same knowledge and experience or skills, which means that each private company has the ability and expertise in its respective fields to carry out an activity or job (Pisar and Bilkova, 2019). For example, a company in the field of housing (real estate) as the owner of the land may not necessarily be able to carry out development on the grounds of insufficient capital. For this reason the developer company invites cooperation with companies in the field of development (contractors). This paper aims to discuss Joint Operation as the main theme, considering that Joint Operation (JO) is often found in practice as a pattern or model of cooperation in the construction of infrastructure projects.

\section{Joint Operation as a Quasi Legal Entity}

Joint Operations can be classified as quasi legal entities (shadow legal entities) because Joint Operations are executed by group of parties which collaborate in developing or completing the implementation of a project integrated in the Joint Operation agency. Joint Operation is a party authorized to act for and on behalf of the entities forming this Joint Operation. Decision power in a Joint Operation body that can be formed by the Board of Directors who acts as an executive body to carry out 
the activities of the Joint Operation entity. The responsibilities of the Board of Directors are formed and agreed upon by the participants in the Joint Operation entity and this is reflected in the cooperation agreement. People appointed to hold positions in the Board of Directors are referred as Directors who are authorized to act for and on behalf of the Joint Operation agency. The duties and positions of the Director in a Joint Operation body are the same as those of a Director in a Limited Liability Company. The Directors in the Joint Operation Agency are also given the duties, authority and responsibility to carry out daily work such as running the company daily and carry out company's policy.

Because a Joint Operation is a quasi legal entity (not a formal legal entity), Joint Operation as a body cannot own assets independently and is separated from participants in Joint Operations, both in the form of movable or immovable property. If there are assets that are already owned or will be owned, then the assets are named for one or all participants in the Joint Operation in accordance with the agreement. This is different from a Limited Liability Company, Foundation or Cooperative which is a legal entity that can have its own assets separated from the wealth of its founders.

\section{Mutual Funds of Collective Investment Contract}

Joint Operation as a quasi legal entity or shadow legal entity (pseudo legal entity) has similarities with investment institutions, namely Mutual Funds in the form of Collective Investment Contract (Siagian, 2016). In Article 1 of Law No. 8 of 1995 concerning the Capital Market (Gautama, 1997), it is stated that an Investment Fund is a container used to collect funds from the community of investors to be subsequently invested in a Securities Portfolio by the Investment Manager. Investment Manager is the person in charge of managing Securities Portfolios for clients or managing a Collective Inventory Contract portfolio for a group of clients. Basically, there are two forms of Mutual Funds, in the form of a Company and in the form of a Collective Investment Contract. If it is in the form of a company, the Investment Fund container is a Limited Liability Company, either a closed LLC or a public listed LLC. If the Investment Fund is a Limited Liability Company, it is clear that the Investment Fund institution is a legal entity that is approved by the competent agency, so that it becomes a legal subject. Because as a legal subject, all Mutual Fund activities are carried out by and under the auspices of a Limited Liability Company that has obtained an operating license from the Financial Services Authority.

Meanwhile, Mutual Funds in the form of Collective Investment Contracts can only be made based on contracts or agreements (Article 18 paragraph 1 and paragraph (4) of Law number 8 of 1995). Based on Bapepam-LK Regulation Number IV.C.5 - and Decree of the Chairman of Bapepam-LK Number Kep-43/BL/2008 concerning Mutual Funds in the Form of Limited Participation Collective Investment Contracts, it is explained that Mutual Funds in the form of Limited Participation Collective Investment Contracts are containers used to collect funds from professional financiers who are then invested by the Investment Manager in the securities portfolio. 
Therefore, the definition of a Collective Investment Contract is a contract between an Investment Manager and a Custodian Bank that binds the Participation Unit holder. The unit holder is the Investment Manager who is authorized to process the collective investment portfolio, while the Custodian Bank is authorized to carry out collective safekeeping. The parties involved in the investment participation contract are the Investment Manager with the Custodian Bank that binds the people who invest their money in the form of securities/stock portfolios. The characteristics of the KIK are similar to Joint Operations. The Operational Cooperation Agreement is similar or almost the same as the contract model between the Investment Manager and the Custodian Bank in KIK. Both are outlined in the agreement containing the provisions regarding investment and procedures for its management. Investment Manager is the party that carries out activities and manages investments in a KIK that is very similar to the Directors in collaboration with the Joint Operation (JO) model. Both Investment Managers at KIK and Directors at Joint Operations are acting together for and on behalf of the business entity.

The agreement or contract made between the Investment Manager and the Custodian Bank at KIK binds investors as buyers of securities portfolios in the Collective Investment Contract. Because the Collective Investment Contract as a forum to collect funds from the public, especially professional financiers, the Collective Investment Contract formed under a contract/agreement can be categorized as a body that does not require authorization from the authorized institution.

Nevertheless, Investment managers who are authorized to manage security portfolios can act for and on behalf of the Collective Investment Contract, so that the investment container in the form of a Collective Investment Contract can be referred to as a pseudo legal entity. These characteristics are almost the same as the form of an Operational Cooperation agreement undertaken in the execution of a project, which is also qualified as a pseudo legal entity. Therefore, between KIK and Operational Cooperation there are similarities while both of them can be categorized as quasi legal entities.

\section{Joint Operation in Practice in Indonesia}

Joint Operation as one of the models of cooperation in the implementation and completion of projects, of course involves the participation of parties that have the potential or expertise in their field or those that have special authority to operate the work. One party, for example, as a company owning the land, but does not have enough capital to cultivate the land, can make a collaboration within the form of an Operational Cooperation model with other parties. In this collaboration, participants are expected to support each other to carry out the project development in such a way that the construction of facilities and infrastructure for the benefit of the parties can be achieved in a very effective way. 
The formation of a Joint Operation body begins with an agreement between the prospective participants who want to carry out cooperation in building and carrying out certain projects. The facilities and infrastructure that have been built will be run or managed jointly among the participants by forming or establishing a Joint Operation body. The formation of the Joint Operation is carried out by using a certain name according to the name of the project to be built and operated according to a mutual agreement. Within the Joint Operation body, people who have been appointed by the parties are assigned to sit as participants in the Joint Operation body. The implementation of the Joint Operation in the construction of the project by the parties was carried out by establishing cooperation in the planning, supervision, construction and marketing of the apartment. In the collaboration, there are two parties, namely the land provider and the fund provider who has expertise in the field of development planning and marketing. Between the land provider and the fund provider jointly agreed to form a Joint Operation.

In carrying out the work of the apartment construction project, the parties jointly agreed to appoint and authorize the Joint Operation Agency represented by the Joint Operation Board of Directors. The director is in charge of carrying out the planning, construction, operation and marketing or sale of the apartment including the administration of the required permits. The land owner surrendered the land to the Joint Operation Board of Directors and the capital owner through the Joint Operation Agency financed the construction of an apartment project on land provided by the land owner. If the funds are insufficient to finance the construction of the apartment, the capital owner with the approval of other JO participants, can obtain financing from banks or other financial institutions through loans or credit. The loan or credit can be bound with collateral in the form of objects, namely land / land included as capital in the cooperation. Directors in operational cooperation are given the authority to bind the goods included in the cooperation as collateral for debt to banks or financial institutions. If the apartment project construction has been completed, then the sale of apartment units to consumers (end users) is carried out by the Joint Operation Directors who act as the attorney from and on behalf of the land owner. The profits from the operation and sale of apartments by the Joint Operation Directors (JO) will be divided among the parties according to the percentage agreed upon in the cooperation agreement. The percentage of each party's part is determined according to the value of capital invested in the Operational Cooperation.

As explained earlier, Joint Operation is a quasi legal entity. Although Joint Operations are classified as quasi legal entities, Joint Operations can be subject to bankruptcy. If a Joint Operation is unable to fulfill its obligations to creditors, a Joint Bankruptcy application can be submitted to the Commercial Court. Bankruptcy of Joint Operation as a legal entity is not necessarily directed at the parties incorporated in the Operational Cooperation. Just like a Limited Liability Company, bankruptcy of a company is not necessarily directed at the investors in the company.

\section{Conclusion}


Joint Operation is a model of cooperation between two parties, where the first party owns or provides facilities, and the other party is the owner or provider of funds or having the ability or expertise to support the implementation of the work or project. Joint Operation or Joint Operation is included in the qualifications of the Agency as stipulated in article 3 paragraph (1) Government Regulation Number 1 of 2012 concerning the Implementation of Law Number 8 of 1983 concerning Value Added Taxes on Goods and Services and Sales Tax on Luxury Goods as already several times amended, last amended by Law Number 42 of 2009.

Joint Operation is not a formal legal entity, but as a quasi legal entity, because the formation of a Joint Operation body is based on mutual agreement, without having to obtain authorization from the authorities. Nevertheless, the Joint Operation body can act as represented by the Board of Directors as well as a Limited Liability Company. Because a Joint Operation body is a quasi legal entity, it cannot have separate assets or assets separated from the assets of the participants. Existing or new assets will remain under the authority of each participant according to the agreement stated in the agreement. The form of joint operation is similar to investment institutions, namely mutual funds in the form of collective investment contracts (KIK) which are also categorized as quasi legal entities.

\section{References:}

Cieślik, A., Hien Tran, G. 2019. Determinants of outward FDI from emerging economies. Equilibrium. Quarterly Journal of Economics and Economic Policy, 14(2), 209-231. doi: 10.24136/eq.2019.010.

Gautama, S. 1997. Recent Developments Concerning Investment in Indonesia (with Special Reference to the New Company Law 1995). Sing. J. Int'l \& Comp. L., 1, 117.

Jayady, A., Pribadi, K.S., Abduh, M., Bahagia, S.N. 2013. A Study of Joint Operation Scheme in Indonesia. The 6th Civil Engineering Confrence in the Asian Region, 20-22.

Koppenjan, J.J.F. 2005. The formation of public-private partnerships: lessons from nine transport infrastructure projects in the Netherlands. Public Administration, 83(1), 135157.

Ophiyandri, T., Istijono, B., Hidayat, B. 2017. Joint-operation in water resources project in Indonesia: Integrated or non-integrated. In AIP Conference Proceedings, 1903(1).

Paul, S. 1987. Community participation in development projects. World Bank, WDC.

Pisar, P., Bilkova, D. 2019. Controlling as a tool for SME management with an emphasis on innovations in the context of Industry 4.0. Equilibrium. Quarterly Journal of Economics and Economic Policy, 14(4), 763-785. doi: 10.24136/eq.2019.035.

Siagian, V. 2016. The Performance of Collective Investment Contract of Stock Mutual Fund In Indonesia. Business and Entrepreneurial Review (BER), 6(1), 39-43.

Wibowo, A. 2005. Estimating general threshold traffic levels of typical build, operate, and transfer toll road projects in Indonesia. Construction Management and Economics, 23(6), 621-630.

Wibowo, A., Permana, A., Kochendörfer, B., Kiong, R.T.L., Jacob, D., Neunzehn, D. 2012. Modeling contingent liabilities arising from government guarantees in Indonesian BOT/PPP toll roads. Journal of Construction Engineering and Management, 138(12), 1403-1410. 